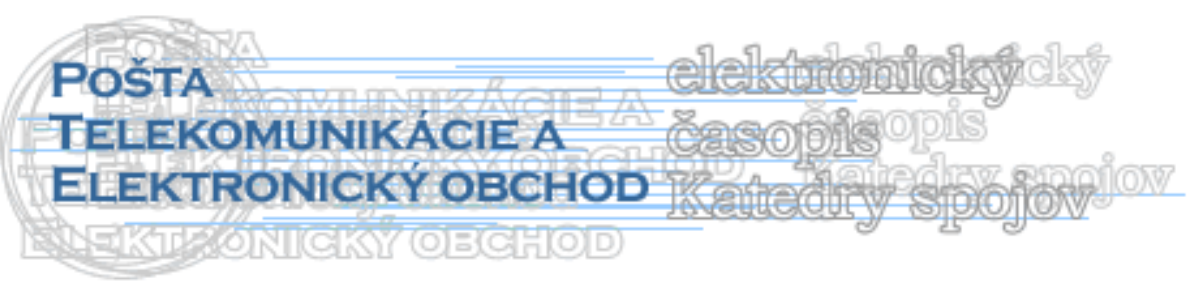

\title{
ZMĚNA PROCESŮ A VZTAHŮ STATU \\ K OBČANOVI POMOCÍ EGOVERNMENTU
}

\author{
Marcela Hrdá ${ }^{1}$ Iveta Kremeňová ${ }^{2}$
}

\section{Úvod}

eGovernment mění a vásledujícím období bude nadále radikálně měnit způsob fungování státní a veřejné správy. Poštovní služby jsou v uplynulých letech vystaveny zásadnímu dopadu elektronické substituce. Současně lze konstatovat, že liberalizace poštovních služeb otvírá prostor pro poskytování nových služeb. Tyto dva rozměry vytvářejí prostor pro vstup poštovních operátorů do světa elektronických služeb. Tradiční poštovní operátoři jsou po mnoho let a v mnohých situacích partnery státu. Právě proto je zcela logické, že se stávají partnerem státu i v oblasti elektronizace státní správy - partnerem eGovernmentu.

\section{Efektivnější eGovernment prostřednictvím transformace procesů}

\section{1. eGovernment jako proces elektronizace státní správy}

Co všechno rozumíme pod pojmem eGovernment? „Elektronizace státní správy,“ „přechod na moderni systém komunikace s občany,“ nebo „změna způsobu fungováni státní správy."

Mnohem víc je ale nutné mluvit také o změně procesů, o změně přístupu státní a veřejné správy k občanovi, o otevření nových možností komunikace státu s občanem. Tyto rozměry jsou ale částečně opomíjeny a to přesto, že v následujícím období budou klíčové. eGovernment nemůže být postavený pouze v prostoru, který mu určí státní moc, ale musí respektovat také potřeby a očekávání občana.

eGovernment se na počátku chápal jako proces elektronizace existujících služeb státní a veřejné správy, což znamenalo, že by se existující procesy pouze převedly do elektronické formy. Posláním eGovernmentu ale není, abychom se pouze ocitli v elektronickém světě, ale aby došlo k radikálnímu zefektivnění služeb státní a veřejné správy, čímž postupně dojde $\mathrm{k}$ celkové transformaci veřejné správy.

eGovernment se následně posunul do jiné dimenze. Základem se tak postupně stává řešení jednotlivých životních situací obyvatel a podnikatelů. V tomhle pohledu lze pak efektivně měnit i samotné procesy a až následně je elektronizovat.

\footnotetext{
${ }^{1}$ Ing. Marcela Hrdá, Žilinská univerzita v Žiline, externá doktorandka na FPEDAS, Katedra spojov, Univerzitná 8215/1, 01026 Žilina, Tel.:+421415133100, 101

${ }^{2}$ Doc. Ing. Iveta Kremeňová, PhD., Žilinská univerzita v Žiline, FPEDAS, Katedra spojov, Univerzitná 8215/1, 01026 Žilina, Tel.:+421415133100, 101, e-mail: iveta.kremenova@fpedas.uniza.sk
} 
Cílem je zjednodušit administrativu pro občana do té míry, že jeho kontakt se státní správou se omezí na minimum a to $\mathrm{z}$ důvodu automatických kroků, které státní správa v prospěch občana učiní. Služby pak musí splňovat podmínku časové i geografické dostupnosti a pohodlí (v budoucnu ideálně z prostředí domova). Napřr. u změny trvalého bydliště musí občan komunikovat s mnoha institucemi a opakovaně činit stejný úkon. Spuštění základních registrů v České republice umožní, že tento úkon bude činěn pouze jednou.

Do budoucna lze očekávat, že eGovernment překročí hranici státní a veřejné správy a propojí se s komerčními subjekty. Množství úkonů, které by občan v rámci určité životní situace činil, se tak bude dále snižovat (např. zavedení informací o změně trvalého bydliště do bankovního systému).

\subsection{Procesní transformace veřejné správy a lidské zdroje}

Základem pro změnu fungování státní a veřejné správy nemůže být pouhá změna informačního a komunikačního kanálu, ale faktická změna ve formě transformace procesů.

Tento koncept je nutné zásadnějším a transparentnějším způsobem dostat do dalšího rozvoje eGovernmentu. Pouze procesy, které budou rychlejší, efektivnější a levnější zaručí, že občan je bude využívat a současně respektovat a budou pro něho znamenat přidanou hodnotu. V opačném př́ípadě se dostává občan (ale i stát) do situace, kdy hledá postupy jak nadměrnému administrativnímu zatížení uniknout.

Nezbytnou součástí procesní transformace státní a veřejné správy je ovšem také vyřešení otázky lidských zdrojů. Lidský faktor ovlivňuje změnu procesního nastavení zásadním způsobem - pouze pokud se najdou nástroje a motivační postupy pro podporu změny ze strany státních úředníků, kteří současné procesy vykonávají a řídí, nastartuje se zásadní reorganizace a zefektivnění těchto procesů. Pokud se ale naopak budou vykonavatelé současných procesů cítit ohroženi jejich radikální změnou, bude docházet k možné blokaci (minimálně k pasivitě) transformačních změn a kýžený efekt bude maximálně poloviční. Součastí jednotlivých projektů eGovernmentu tak musí být do budoucna řešení otázky lidských zdrojů a motivace ke změně.

\section{2. eGovernment v prostřredí poštovního operátora}

Jedním ze zásadních faktorů úspěšnosti konceptu eGovernmentu je jeho dostupnost. Pokud míra penetrace vysokorychlostním internetem nenabyde zásadnějších rozměru a počítačová gramotnost se nerozšíří mezi všechny sociální a demografické vrstvy obyvatelstva, lze očekávat, že v následujícím období bude nadále docházet ke kombinaci elektronických služeb podporovaných lidským faktorem.

Tradiční poštovní operátoři jsou partnerem státu od nepaměti a patří mezi nejvíce důvěryhodné subjekty (podle průzkumu společnosti GfK Czech byli pracovníci pošty druhým nejdůvěryhodnějším povoláním, věří jim přes $93 \%$ dotázaných a to $\mathrm{v}$ průzkumech $\mathrm{z}$ roku 2010 i 2011).

Pokud tedy uvážíme nutnost dostupnosti služeb eGovernmentu a budeme vyžadovat vysokou míru důvěryhodnosti, která je pro poskytování těchto služeb nezbytná jelikož se jedná o osobní data občanů, nabízí se poštovní operátor, který má rozsáhlou geografickou působnost a zmiňované důvěry občanů požívá, jako logický partner státu v oblasti eGovernmentu. Poštovní operátor $v$ mnoha př́padech disponuje rovněž moderním technologickým a technickým vybavením vzhledem k tomu, že musel v uplynulých letech přistoupit k radikální modernizaci a elektronizaci svých služeb. Nespornou výhodou poskytování služeb eGovernmentu prostřednictvím poštovního operátora je rovněž možnost 
využití lidského potenciálů poštovních pracovníků, kteří jsou zvyklí poskytovat elektronické, finanční a poradenské služby občanovi na každodenní bázi.

Jedním z nejzajímavějších příkladů poskytování služeb eGovernmentu prostřednictvím poštovního operátora je bezesporu provozování tzv. Czech POINT-ů na České poště, s.p. Na Czech POINT-ech občané získávají veškeré údaje, opisy a výpisy, které jsou vedeny v centrálních veřejných evidencích a registrech o jejich osobě, majetku a právech. Odpadává tak další obíhání po úřadech dle hesla „nemá obíhat občan, ale dokument“. Jak je vidět na obrázku č. 1, tak přesto, že Česká pošta, s.p., provozuje „pouze“ $14,19 \%$ ze všech pracovišt' Czech POINT-ů, její podíl na trhu v počtu vydaných výstupů je přes $50 \%$. Tento úspěšný projekt tak otvírá dveře dalším službám a projektům v oblasti e-Governmentu a potvrzuje tak, že eGovernment nemůže být formován pouze státem, ale i požadavky a přáními občanů.

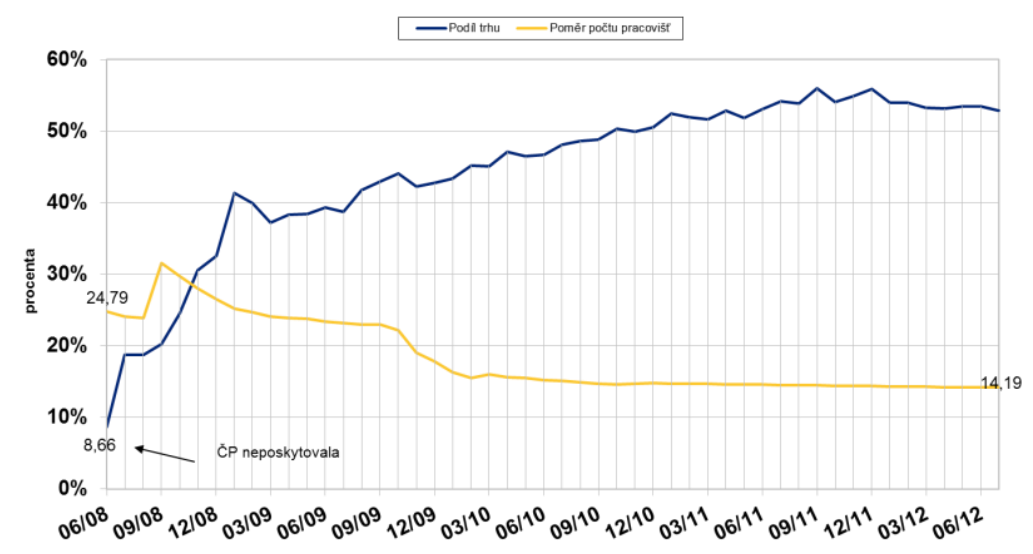

Obr. 1: Podíl České pošty, s.p., na trhu z celkového počtu vydaných výstupů Czech POINT k poměru počtu pracovišt' Czech POINT na České poště, s.p. (Zdroj: Česká pošta, s.p., divize ICTG)

\section{Závěr}

Co dnes rozumíme pod pojmem informační společnost? Je společnost, která se ve stále větší míře opírá o shromažd'ování, využívání a šíření informací [1].

Z technologického pohledu lze říci, že informační společnost je společnost s vysokou mírou využívání informačních a komunikačních technologií založených na prostředcích výpočetní techniky a s nimi spojenou digitalizací [2].

eGovernment se tak musí stát pilířem informační společnosti v jednotlivých státech. Pokud bude státní správa fungovat v efektivním, moderním a elektronickém světě, kde shromažd'ování, využívání a šíření informací je ku prospěchu občana, budou další části informační společnosti fungovat mnohem efektivněji a rychleji.

Je ale potřebné se uvědomit, že budování informační společnosti je služba - v př́padě eGovernmentu je to služba občanům i státu a její rozvoj nikdy neskončí. I proto je nutné, aby součástí architektury, projekti̊ a budování jednotlivých funkčních celků byly také programy udržitelnosti a správy systémů, informační bezpečnosti, čistoty dat, dalšího rozvoje funkcionality systémů $v$ souladu s potřebami občanů $i$ státu a dostupnosti systému. Jednorázová řešení by znamenala krok do prázdna, který by v krátkém čase přinesl duplicity a zneefektivnění procesů a znamenal by také zmaření investic. 


\section{Literatura}

1. SOKOL, Jan. Filosofická antropologie: Člověk jako osoba. Vyd. 2. -- Praha : Portál, 2008. -- 224 s., ISBN 978-80-7367-422-9 Oddíl „Společenská komunikace“, str. 77-80.

2. FROULÍK, Radek. Nová ekonomika a globální informační společnost. http://interval.cz/clanky/nova-ekonomika-a-globalni-informacni-spolecnost/

„Príspevok vznikol za podpory nasledovných grantových projektov: VEGA 1/0199/11- Výskum interoperability metód riadenia so strategickým zámerom organizácie a KEGA 052ŽU-4/2012 On-line riadenie výučby v procese vzdelávania v oblasti IKT.“ 